\title{
The Influence of Visual Media on the Footwork in Badminton
}

\author{
Abdillah \\ Master Program in Sports Sciences \\ Yogyakarta State University \\ Yogyakarta, Indonesia \\ abdillah.2017@student.uny.ac.id
}

\author{
Lismadiana \\ Faculty of Sport Sciences \\ Yogyakarta State University \\ Yogyakarta, Indonesia \\ lismadiana@uny.ac.id
}

\begin{abstract}
- this research is aimed at studying the influence of visual media on badminton footwork of the learner Class VIII Junior High School Negeri 2 Mempawah Hilir, Indonesia. The purpose of this study was to determine the influence of visual media on learning badminton. The research method used in the experiment was true experiment study design. The population of the research included class VIII. Sampling was done through the use of purposive sampling technique which was categorized into class VIII $A$ and B, were 18 learners were used as control class and other 18 learners as an experimental class. Data was analyzed using the computerized system and t-test. Based on the results of the t-test on grade control, experimental value was 0,000 which is $<0.05$ as a result of this $\mathrm{Ho}$ is rejected (Ha accepted). This means that there is influence of visual media on footwork in badminton game Visual learners in class VIII SMP Negri 2 Mempawah Indonesia in the experimental class with a mean value of $21 \%$ than in the control class $(4 \%)$. Based on the results of this study, it was concluded that visual media can help in improving the footwork of badminton athletes in junior high schools.
\end{abstract}

\section{Keyword—visual media, footwork, badminton}

\section{INTRODUCTION}

Footwork is the basis for the production of quality blows when it is done in a good position. To be able to hit in a good position, a player must have a speed of movement. The speed of footwork cannot be achieved if the footwork is irregular [1]. Footwork (foot movements) is very important for badminton athletes. Footwork helps an athlete to move in any direction as efficiently as possible [2]. Footwork is the most basic skill in badminton matches and it is very important in having achievements in the game. Footwork allows a player to reach the shuttlecock quickly [3]. Badminton footwork has to do with moving around the direction of the game field itself in returning the ball to the opponent's area [4]. Badminton footwork requires the ability to move in the area itself to get a moving position and return position and at the same time maintaining a balance [5]. The students of class VIII of Mempawah Hilir 2 Junior High School of Mempawah in Indonesia Regency have footwork and agility that are below average, judging from the initial tests in the instrument that have been validated. As a result of this, they need to be trained to increase their footwork and agility.

Achieving footwork that can produce quality agility and blows can be done through the use of various media including 3-color lamp signals [1]. Visual reactions are needed to respond to visual stimuli [2]. The visual media works is such a way that it stimulates the visual stimulus when the device emits light [3]. With the advancement of time and technological development, high-tech badminton equipment takes an increasingly important role in improving athletes' skills [4]. Visual media is one alternative that captures the essence of seeing shuttlecock which results in a motion reaction to be able to hit it [5].

Visual media is an implementation that is integrated to help improve footwork agility. Visual media will help in increasing footwork and agility in the form of video, step footprints and colored lights. The reaction lamp media is a device that is used as a direction or shadow badminton movement. The reaction in badminton, where six lights are mounted in the middle of the back of the Net, is that it can improve the basic footwork quality in badminton.

\section{METHODS}

The method used is the experimental method and the research design employed is the True Experimental Design with the Pretest-Posttest Control Group Design form. The instrument used was the assessment of badminton footwork motion. Data collection techniques employed were tests and measurements and the sample technique used was systematic sampling. Systematic sampling is a sampling technique based on the order of members of the population that have been numbered.

\section{RESULT}

The results of the research on the influence of visual media on badminton footwork show that the pretest in the control class was $50.5 \%$ and that the posttest was $55.5 \%$ with a percentage increase in the basic ability of badminton footwork found to be $4 \%$. The pretest of the experimental class was found to be $52.5 \%$ while the post-test was $73.5 \%$ with a percentage increase in the basic ability of badminton footwork by $21 \%$. In the experimental class the percentage increase is higher than in the control class, this is certainly influenced by visual learning media that was applied to the learning process.

\section{DISCUSSIONS}

This research was an experiment to improve student learning outcomes, by the use of footwork material in the badminton game of Mempawah Hilir 2 Junior High School students in Mempawah Regency. The media used were lights and images that are attached as a step to step by students. In this study, the research process was carried out by looking at the basic abilities of students through the initial test (pretest), then given the training process on the footwork material using the media (experimental class). The learning process or 
treatments were carried out according to the extracurricular schedule of physical education and health in 10 meetings at a frequency of 2 times in a week and each meeting was held as an evaluation. Therefore, at the 8th meeting, the researchers saw significant development of the students, then the posttest was done at the 9th meeting. The final test was used to compare the initial and final abilities after learning, from all the 10 meetings.

Based on the results of this study, differences were observed. The research revealed the basic abilities of the students through the initial test (pretest) as well as their abilities after the implementation of the visual media. The calculation results of the t-test UI using SPSS Version 20 for the basic footwork test on badminton games had a $p$ value $=$ $0,000<0,05$, therefore, Ho is rejected (Ha is accepted). This means that there is a significant increase in the pretest and posttest activities due to the influence of the usage of Visual media, and also reflects the influence of the use of visual media on footwork in badminton learning for eighth grade students of Mempawah Hilir 2 Junior High School 2 in Mempawah Regency. The results of this study showed that modification in learning can increase success in training results.

\section{CONCLUSION}

Based on the results of the study, it was concluded that there was an influence of visual media on badminton game footwork in the experimental class with a score of $21 \%$ pretest and posttest, based on the results of the t-test, $p$ value $=0,000$ $<0.05$, Ho was rejected (Ha accepted). Therefore, an effect of visual media on footwork quality was established.

\section{ACKNOWLEDGMENT}

Many thanks to my parents who have supported me and always patiently suggest not to give up on the task and carry out the obligation. I also thank all the students of SMP N 2 Mempawah Hilir Indonesia who are involved in this study as well as physical, sports and health education teachers who contributed to the research process. My appreciation also goes to the lecturers and friends of students of the sports science study program at the Postgraduate Program of Yogyakarta State University, Yogyakarta.

\section{REFERENCE}

[1] M. F. Yuksel, \& G. Tunc, "Examining the reaction times of International level badminton players under 15," Sports, 6, 2018.

[2] I. T. Ni'mah. \& Deli, Mateus, "Buku pintar bulutangkis," Jakarta Timur: Anugerah. 2017.

[3] M. K. Bhabhor, "A comparative study of visual reaction time in table tennis players and healthy controls". Indian j physiol pharmacol. , 2013, 57 (4) : 439-442.

[4] Nugraha. Febby, "Pengembangan sinyal lampu 3 warna untuk alat bantu kelincahan footwork pada klub PB.Mandiri Pati", Tesis. Semarang: Universitas Negeri Semarang, 2015.

[5] Y. Hong, S. J. Wang, K. W. Lam, T. M. Cheung, "Kinetics of badminton lunges in four directions," Journal of Applied Biomechanics Human Kinetics, Inc, 2013.

[6] Z. Q. Liang, \& J. S. Li, "Progresses of the badminton equipment relate to exercise: Some training aspects," Some training aspects. J Sports Med Ther. 3: 001-009, 2018

[7] H. Lin, K. T. Tong, C. Huang, J. Nie. Lu., K. Quach, "Specific inspiratory muscle warm-up enhances badminton footwork performance," Applied Physiology Nutrition and Metabolism, 2007.

[8] Chen, Chao, "Footwork teaching of college badminton elective course," International Conference on Science and Social Research, 2014. 